\title{
THE CORRELATION BETWEEN THE HISTORY OF HYPERTENSION AND PREECLAMPSIA
}

\author{
Sukmawati $^{1}$, Lilis Mamuroh ${ }^{2}$, Furkon Nurhakim $^{3}$ \\ ${ }^{1,2,3}$ PSDKU Garut Universitas Padjadjaran, Garut, Indonesia \\ Correspondence: ahmad.sukma@yahoo.co.id, lilis.mamuroh65@gmail.com,n_hakim019@yahoo.co.id
}

\begin{abstract}
The maternal mortality rate in Garut Regency was 74 cases in 2016 and $25 \%$ of them was due to preeclampsia. There were 96 pregnant women treated for Preeclampsia from January to November 2017 in the Kalimaya Room of Dr. Slamet Garut Hospital. Preeclampsia is an increase in blood pressure in pregnant women after 20 weeks of pregnancy and proteinuria. The purpose of this study was to determine the relationship between the history of hypertension and the incidence of preeclampsia in the Kalimaya Room of Dr. Slamet Garut Hospital. This research applied the analytic correlation method with Case-Control approach. Simple Random Sampling was chosen, and the number of samples was 49 respondents as the case group and the control group was 98 respondents. Data were analyzed using univariate, bivariate analysis with Chi-Square test. The results showed a relationship between the history of hypertension $(\mathrm{p}=0.0001)$ and the incidence of preeclampsia. The results of this study are expected to be a reference for families to get to know as early as possible the risk factors for preeclampsia, especially a history of hypertension. Health workers can provide counseling to pregnant women about interventions to prevent preeclampsia and its treatment.
\end{abstract}

Keywords: hypertension, preeclampsia, pregnancy

\section{INTRODUCTION}

Maternal Mortality Rate (MMR) is one indicator of health status. But every day about 800 women dies due to pregnancy and childbirth. Almost all maternal deaths (99\%) occur in developing countries. Based on the Indonesian Demographic and Health Survey (IDHS) in 2012 maternal mortality (MMR) in Indonesia was 359 per 100,000 live births. The 5th Global MDGs (Millennium Development Goals) and Sustainable Development Goals (SDGs) target were to reduce the Maternal Mortality Rate (MMR) to 102 per 100,000 live births in 2015. However, in 2015 the target was not reached, the Maternal Mortality Rate is still high 305 per 100,000 live births. From the health status of pregnant women, $28.8 \%$ of them suffer from hypertension (preeclampsia) and result in cardiovascular disorders that are the cause of maternal death during childbirth (Ministry of Health, 2016).

According to WHO (2014), the main complications (80\%) of maternal mortality are bleeding (bleeding after childbirth), infection (after childbirth) high blood pressure during pregnancy (preeclampsia and eclampsia) and unsafe abortion. The incidence of preeclampsia- 
eclampsia varies in various countries, in developed countries from 0.05 to $0.1 \%$, while developing countries are $-0.7 \%$ (Fitriyati et al, 2017). According to the Preeclampsia Foundation, women in developing countries are seven times more risk of preeclampsia than women in developed countries, and $10-25 \%$ of the cases related to maternal deaths.

In Indonesia, pre-eclampsia-eclampsia is a cause of perinatal death (30-40\%), however, in some hospitals in Indonesia the death cases have shifted, bleeding is a major cause of maternal death. Preeclampsia occurs in approximately 5\% of all pregnancies, $10 \%$ of first pregnancies and $20-30 \%$ in the prim gravid with a history of chronic hypertension before pregnancy.

The main health problem faced in Indonesia and other developing countries is the high maternal mortality rate. Hypertension is a medical problem that often appears during pregnancy and causes 2-3\% complications. According to the Indonesian Health Demographic Survey (IDHS) in 2012 showed that $30 \%$ of the causes of Maternal Mortality Rate (MMR) were Preeclampsia. The maternal mortality rate in West Java has decreased, from 800 cases in 2015 to 780 cases in 2016. In opposite, the number of cases of mothers died in Garut Regency has increased from 45 cases in 2015 to 74 cases in 2016 . The cause of maternal death was $34.3 \%$ of bleeding and $25 \%$ of preeclampsia (Garut District Health Office, 2017)

Preeclampsia is a significant cause of maternal morbidity and mortality. Preeclampsia occurs in 3-7\% of pregnancies (American Academy of Pediatrics \& ACOG, 2007 in Lowdermilk, 2013) Preeclampsia is hypertension that arises 20 weeks' gestation and proteinuria (Praworihardjo, 2014). Preeclampsia is a complication in pregnancy, labor and postpartum that cannot be prevented. Action needs to be taken to prevent complications and avoid risk or predisposing factors of preeclampsia. Predisposing / risk factors for preeclampsia according to Wiknjosastro (2008) are prim gravida under the age of 20 years, 
mothers over 35 years, Parity: prim gravida has almost twice the incidence; heredity (genetic) (Chapman, 2006); history of pre-pregnancy disease including hypertension.

Dr. Slamet Garut General Hospital is the largest Referral Hospital in Garut Regency which serves maternity cases health services. There were 96 cases of preeclampsia treated in the Kalimaya Room in January 2017 to November 2017. The purpose of this study was to determine the relationship between the history of hypertension and the incidence of preeclampsia in the Kalimaya Room of Dr. Slamet Garut Hospital.

\section{METHODS}

This research applied an analytical method with the case-control correlation approach. The type of data used in this study was secondary data. The technique of collecting data was by studying documents, namely medical records of patients treated in the Kalimaya Room at Dr. Slamet Hospital. The population in this study was 96 post-partum women with a history of preeclampsia treated in the Kalimaya Room of Dr. Slamet Garut Hospital. The sampling technique was Simple Random Sampling with a total sample of 49 case groups and 98 respondents in the control group. Data were analyzed using univariate analysis including the history of hypertension and the incidence of preeclampsia. To determine the relationship of independent variables: the history of hypertension and the dependent variable the incidence of preeclampsia using Chi-Square Test.

\section{RESULTS}

The relationship between the history of hypertension and preeclampsia in the Kalimaya Room of Dr. Slamet Garut Hospital is described in table 1 below:

Table 1 Respondents' History of Hypertension

\begin{tabular}{ccccccc}
\hline History of & \multicolumn{2}{c}{ Cases } & \multicolumn{2}{c}{ Control } & \multicolumn{2}{c}{ Total } \\
\cline { 2 - 7 } Hypertension & f & $\%$ & f & \% & f & \% \\
\hline History & 7 & 14.3 & 22 & 22.4 & 29 & 19.7
\end{tabular}




$\begin{array}{lllllll}\text { No History } & 42 & 85.7 & 76 & 77.6 & 118 & 80.3\end{array}$

Table 1 presents that almost all of the case group respondents $(85.7 \%)$ did not have a history of hypertension, similarly, $77.6 \%$ of respondents in the control group did not have a history of hypertension.

Table 2 The Relationship Between Hypertension History and The Incidence of Preeclampsia

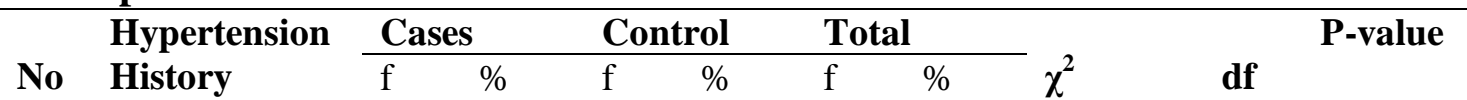

\begin{tabular}{lllllllllll}
\hline 1 & History & 7 & 14.3 & 22 & 22.4 & 29 & 19.7 & & \multirow{2}{*}{0.0001} \\
2 & No History & 42 & 85.7 & 76 & 77.6 & 118 & 80.3 & 53.188 & \multirow{2}{*}{1} & \multirow{2}{*}{$\begin{array}{l}\text { N } \\
\text { Total }\end{array}$} \\
\hline
\end{tabular}

OR $=20.727$

Table 2 explains the results of the Chi-Square test showed a relationship between the history of hypertension and the incidence of preeclampsia p-value 0.0001 ( $\mathrm{p}$-value $<0.05)$ and OR 20.727 means the probability of preeclampsia in respondents who have a history of hypertension 21 times higher than respondents did not have a history of hypertension.

\section{DISCUSSION}

Preeclampsia is a condition in which pregnant women experience hypertension, edema and/or urinary proteins that occur after 20 weeks' gestation (Prawirohardjo, 2008). Preeclampsia is a complication of pregnancy and childbirth which if not detected early, and is not treated quickly and appropriately causes fatal complications. These complications include eclampsia, HELPP syndrome, stroke, failure of various organs, clotting problems. Complications also occur in infants and can even result in intra uterine fetal death. Preeclampsia is a noncommunicable disease but risk in deadly complications such as heart disease, kidney 
disorders, and blindness. One risk factor for preeclampsia includes a history of hypertension, Wiknjosastro (2008).

Women with the history of hypertension is a pregnant woman who has hypertension before pregnancy or before 20 weeks' gestation. Mothers who have a history of hypertension are at greater risk for preeclampsia and may increase maternal and neonatal morbidity and mortality (Cuningham, 2006). In pregnancy the arteries in the uterus will widen from thickwalled muscular arteries, into thin blood vessels with a larger diameter, these changes increase the capacity of blood vessels and adapt to an increase in blood volume. In preeclampsia patients, there is a decrease in placental perfusion and hypoxia. Placental anemia is thought to cause endothelial cell dysfunction, which stimulates the release of toxic substances to the endothelium. This abnormality causes poor tissue perfusion in all organs, increases peripheral resistance and blood pressure, increases endothelial cell permeability, intra-vascular fluid, and protein leakage and ultimately causes reduced plasma volume (Lowdermilk et al., 2013).

The results showed the majority of respondent did not the history of hypertension in the case group (85.7\%) and $77.6 \%$ of respondents in the control group. The results of this study are supported by Sutrimah (2015), most of the preeclampsia respondents did not have a history of hypertension. Yet contrary to the results of Nursal's study (2015) found $41.2 \%$ had a history of hypertension and none in the control group had a history of hypertension.

The results showed that there was a relationship between the history of the disease and the incidence of preeclampsia p-value $0.0001(<0.05)$. The results of this study are in line with Lusiana's (2015) study, she found that there is a relationship between the history of the disease and the incidence of preeclampsia (p-value 0,000) in the Seagull II Room Arifin Achmad Hospital, Riau Province. 
Blood pressure in preeclampsia patients is fluctuating and has a tendency to increase due to vascular resistance that damages the endothelium. This is consistent with the theory that hypertension is a multifactorial disease that occurs due to various factors including age, with increasing age the blood pressure will also increase. After 45 years the artery wall thickens due to collagen buildup in the muscle layer so that the blood vessels will narrow and stiff. Systolic blood pressure increases as our age, the flexibility of large blood vessels decreases until the seventh decade. Stable fifth and sixth diastolic blood pressure then settles or tends to decrease. Addition of age causes physiological changes, in the elderly, there is an increase in peripheral resistance and sympathetic activity. Regulating blood pressure, namely the baroreceptor reflex in the elderly, has decreased sensitivity, while the role of the kidney has also been reduced where renal blood flow and glomerular filtration rate have decreased (Kumar V, 2005).

The results of this study are also in accordance with the literature from the Ministry of Health of the Republic of Indonesia (2006), namely the high rate of hypertension in line with increasing age. This happens because of changes in the structure of large blood vessels so that the lumen becomes narrower and the blood vessel walls become more rigid as a result of increasing diastolic blood pressure. Age is a risk factor that cannot be avoided and is positively related to hypertension so that healthy behaviors are needed. These behaviors include maintaining physical health, reducing risky behaviors such as smoking, staying up late, drinking coffee, alcohol, junk food and other risky behaviors such as degenerative diseases (Kartikawati, 2008). 


\section{CONCLUSION}

The results of this study concluded that there was a relationship between the history of hypertension and the incidence of preeclampsia. The results of this study are expected to be a reference for families to get to know as early as possible the risk factors for preeclampsia, especially the history of hypertension and for health workers can develop management knowledge enhancement interventions in pregnant women, especially in cases of preeclampsia

\section{REFERENCES}

Chapman, V. (2006). Asuhan Kebidanan Persalinan \& Kelahiran (The Midwife's Labour and Birth Handbook). Jakarta : EGC.

Cuningham FG dkk. (2006). Obstetri William. Jakarta : EGC.

Dinas Kesehatan Kabupaten Garut. (2017). Profil Kesehatan Kabupaten Garut tahun 2016. Dinas Kesehatan Kabupaten Garut.

Hidayati Novida dan Kurniawati Titik. (2014). Hubungan Umur dan Paritas Dengan Kejadian Preeklampsia Pada Ibu Hamil di Puskesmas Bangetayu Kota Semarang. Journal Unimus.ac.id. Vol 3 No 1, diakses 3 Maret 2018.

Kemenkes RI. (2016). Profil Kesehatan Indonesia Tahun 2015. Jakarta : Kemenkes RI.

Lowdermilk Deitra Leonard. (2013). Keperawatan Maternitas. Jakarta : Elsevier Mosby.

Lusiana Novita. (2015). Faktor-faktor yang Berhubungan dengan Kejadian Preeklampsia pada Ibu Bersalin di Ruang Camar II RSUD Arifin Achmad Provinsi Riau Tahun 2014. Jurnal Kesehatan Komunitas, Vol 3, No 1, November 2015, Diakses 8 Maret 2018.

Manuaba Ida Bagus. (2012). Pengantar Kuliah Obstetri dan Ginekologi Sosial. Jakarta : Trans Info Media.

Mustafa dkk. (2012). Acomprehensive review of hypertention in pregnancy. J Pregnancy.

Nursal dkk. (2015). Faktor Risiko Kejadian Preeklampsia Pada Ibu Hamil Di RSUP DR. M. Djamil Padang Tahun 2014. http://jurnal.fkm.unand.ac.id/index.php/jkma/, Padang : FKM Andalas.

Prawirohardjo Sarwono. (2014) Ilmu Kebidanan. Jakarta : Sagung Seto. 
Preeklampsia Foundation. (2014). Research New on Preeclampsia. www.preeclampsia.org.

Radjamuda Nelawati, Montolalu Agnes. (2014). Faktor-Faktor Risiko Yang Berhubungan Dengan Kejadian Hipertensi Pada Ibu Hamil Di Poli klinik Obs-Gin Rumah Sakit Jiwa Prof. Dr.V.L. Ratumbuysang Kota Manado. Jurnal Ilmiah Bidan Volume 2 Nomor 1 Januari-Juni 2014 diakses 8 Oktober 2017.

Sutrimah dkk. (2015). Faktor-faktor yang berhubungan dengan kejadian preeklampsia Pada Ibu Hamil Di Rumah Sakit Roemani Muhamadiyah Semarang. Jurnal.unimus.ac.id.

Wiknjosastro H. (2008). Ilmu Kebidanan. Jakarta : Yayasan Bina Pustaka : Rineka Cipta. 